\title{
The shadowland manipulator: Sir Ernest "Booze", John A. Lee, and the Labour Party
}

\author{
JOHN HORROCKS
}

\begin{abstract}
For Mine is the Kingdom, published in 1975, is John A. Lee's tell-all account of his long relationship with Sir Ernest Davis, the Auckland beer baron, philanthropist, mayor, and leading financier of the Labour Party. It is frustrating as an historical document because of Lee's fondness for reconstructed conversations and its semi-novelistic style. As a result, it is often hard to assess the accuracy of Lee's portrayal of the sinister but engaging "Sir Booze." Despite these limitations, it remains the most detailed description of the links between the early Labour Party and the brewing industry. As an exercise in psychobiography it is also only partially successful, yet its description of Davis' relentless womanising and exploitation of his female staff, as well as his financial support for Labour, is emblematic of the shadowy way Davis operated, both in the bedroom and in the interests of his business.
\end{abstract}

A "humdinger," was how the former Labour Party politician John A. Lee described his 1975 memoir about the Auckland brewer Sir Ernest Davis. He speculated that it would get him "ridden on a rail and they'll probably put some broken bottles on it first."1 Journalist Audrey Gordon said that he looked "wickedly pleased at the prospect of being the centre of further controversy," but his account of his relationship with Davis remains one of the least-known of his books. By 1975, almost all of the "they" who might have been offended by Lee's For Mine is the Kingdom were long dead. As Lee said himself: "The girls of his young manhood were mostly dead, the girls of his middle-age had become secretive matrons, even grandmothers; the philanthropist had erased the playboy."2

Lee himself had identified the main reason his book was a flop. No one cared any longer about Davis and forgotten episodes of political corruption in the interests of the liquor trade, much less the tale of the brewer as philanderer, the man who "was lord of jobs when women could not rise above the waitress level and [who] exercised his seigneur's rights." For Mine is the Kingdom joins the company of other unsuccessful attempts to expose political wrongdoing in New Zealand, a history which goes back to James Black's unauthorised biography of Sir Joseph Ward and his fraudulent dealings during the 1890s with the J.G. Ward Farmers' Association. ${ }^{4}$ More than a century later, Nicky Hager's Dirty Politics also made little impact on the general election of 2014 and the career of a prime minister, John Key. ${ }^{5}$ Even the hope that Lee's book might reveal secrets about politically active contemporaries was long past. Despite this limitation, however, it is a significant contribution to the history of both the Labour Party and the power of the liquor industry in New Zealand politics, even if it lacks the authority of a work such as Robert Caro's The Power Broker, the story of perhaps the greatest behind-the-scenes operator of the 20th century, New York's Robert Moses. ${ }^{6}$

Davis may have been a playboy in his early years, but he was a popular mayor of Auckland from 1935-1941 and held office in many sporting and civic bodies, including the Auckland Hospital Board, the Auckland Harbour Board, and the Auckland Metropolitan Fire Board. ${ }^{7} \mathrm{He}$ also served as president of the New Zealand Football Association and was a prominent racehorse owner and yachtsman, well-known for his various crafts on the Auckland harbour. Among them was Auckland's largest schooner, the 80-ton Morewa, but Davis' public-spirited 
character was demonstrated by his gift of another yacht, the Viking, to the New Zealand Navy as a training ship. Brown's Island is now a publicly-owned reserve as a result of Davis' philanthropy, while other substantial gifts to his home city included $£ 100,000$ to establish the Marion Davis Memorial Medical Library in memory of his wife. ${ }^{8}$

For Lee, on the other hand, this admired public figure was also an unscrupulous operator whose principal loyalty was to the brewing industry, or "Trade." He describes Davis' role in typically melodramatic fashion:

Already Sir Ernest Booze is scarcely remembered and yet there was behind the scenes no more sinister figure in New Zealand's political life, a man who owed loyalty to the Trade's investments only, maybe the greatest shadowland manipulator of politics New Zealand is ever likely to see. ${ }^{9}$

Among these manipulations were payments and gifts to several Labour Party politicians; bribes in the form of services in hotels to MPs and officials such as customs officers; and payments to prominent and corrupt union officials. According to Lee, the most blatant act of political interference by Davis was the scheme by which his crooked associate Fred Young, the secretary of the Hotel Workers' Union, arranged to have a weak Labour candidate selected to contest the 1935 Auckland mayoralty, so that Davis could win. Despite the outraged response of some Labour Party members to this deal, Davis was further rewarded by the new Labour Government by receiving a knighthood in $1937 .{ }^{10}$ In For Mine is the Kingdom, Lee finally set out the allegations about Sir "Booze" that he had kept quiet about for so many years. ${ }^{11}$ He also said that Davis admitted that Lee knew so much about him that he was the only man in New Zealand who could blackmail him and the only one who would not try. ${ }^{12}$

Nothing that Lee says in his memoir is self-evidently false, particularly as he gives examples of how he himself was a beneficiary of the Trade's largesse. There are undoubted distortions that come from the semi-novelistic narrative of For Mine is the Kingdom and the fact that Lee is telling the story. Yet his description of the behind-the-scenes power of Davis provides a plausible picture of why the Trade was so willing to finance Labour Party MPs.

\section{Davis, Labour, and Prohibition}

Davis and his brother Eliot had enjoyed a significant role in the brewing industry since 1910, when they took over the management of Hancock and Co. from their father. The political clout of the brewing trade was increased in 1923 with the formation of New Zealand Breweries, an amalgamation of 10 companies distributed throughout the country. Hancock and Co. was a member of this conglomerate and Eliot Davis a founding director. Ernest served as chairman. ${ }^{13}$ Until the emergence of a rival company in 1929, Dominion Breweries, Davis and his associates dominated the liquor industry in New Zealand, as they also owned the hotels they supplied with beer and spirits.

The brewer knew Michael Joseph Savage, who had worked as a cellarman in the Davis family's Captain Cook brewery since arriving in Auckland in 1908. Apart from this personal relationship with the future prime minister, Davis' own financial links with future Labour Party figures went back to 1912 , when he paid the $£ 1600$ bond for the imprisoned leaders of the Waihi strike. They included Bill Parry, who was to become a Labour MP in 1919. Davis' payment might have been a prescient move, an awareness of the growing power of a new workers' movement, but it also fits some of the more complex aspects of a man who was capable of surprising acts of generosity. At the time of the strike, Savage was chairman of the Auckland branch of the Federation of Labour and spoke frequently in support of the Waihi miners. ${ }^{14}$ Davis might well have taken notice. His brother Eliot recalls his own friendly 
relationship with Savage and the occasions when they would wash out the cellar with hoses and brooms, or have lunch together: "Each of us would sit on a beer barrel in the cask shed, and discuss over our bread and cheese, and perhaps a pint of beer, many of the important topics of the day." 15

After the formation of the Labour Party in 1916, these contacts proved to be significant, as the Trade needed the support of any politicians who were not outright prohibitionists. In each of the polls of 1919, 1922, and 1925, prohibition got the highest proportion of votes, but could not manage the $50 \%$ required for success. It is difficult today to appreciate how seriously the Trade feared the destruction of its business through prohibition. Steps short of outright prohibition could also be destructive. Local areas could be declared "dry" and a reduction in the number of hotels could follow. In the 1908 poll, the Davis family's company, Hancock and Co., had lost several of hotels in this way. Eliot Davis complained that this was one of the most damaging consequences of prohibition, as hotels in the "dry" areas were now useless except as boarding houses. Fortunately for the Davis' business, Onehunga, Ellerslie, and Panmure were saved from going "bone dry" in 1908 by the block vote of the alcoholics at the Salvation Army Inebriates Home at Pakatoa Island. ${ }^{16}$ One can only suppose that they were desperate to return to the mainland and resume drinking. Prohibition, for Eliot Davis, meant "confiscation without compensation - in other words it meant daylight robbery." 17

The temperance lobby group, the New Zealand Alliance, had been pushing for prohibition since its formation in 1886 and there were prohibitionists among founding members of the Labour Party and a more conservative predecessor, the United Labour Party. ${ }^{18}$ A daughter of one prohibitionist, George Fowlds, a former cabinet minister in Ward's Liberal government and the chairman of the Auckland branch of the United Labour Party, recalled her embarrassment at having to sing the temperance song "Strike out the top line" at public meetings. ${ }^{19}$ Because alcohol was seen as particularly destructive to workers and their families, as well as being pushed by an exploitative liquor trade, it was inevitable that there would be discussion about its regulation at Labour's first annual conference in 1917. Savage proposed that the party support the option of state control of liquor, but the final decision to support a referendum ballot that included state control, along with prohibition or continuance, so offended the party's president, the prohibitionist James McCombs, that he immediately resigned. ${ }^{20}$ Barry Gustafson has suggested that Savage was possibly influenced by the financial support given to the Labour Party by Davis. ${ }^{21}$ Another explanation might be that Savage thought the addition of state control could bridge some of the divisions within the labour movement. His focus on this issue at the Labour Party conference the following year and his attack there on the evils of excessive drinking suggest that his motivation was primarily to preserve party unity, though he did unsuccessfully propose a scheme for partially compensating the brewing and hotel industries if state control should be carried. ${ }^{22}$

After Lee took the Auckland East seat for Labour in 1922, Davis asked to meet him, an encounter that Lee says was arranged by Savage. When he first entered politics, Savage had advanced him $£ 50$ to buy a suit. Lee later came to believe that the money had actually come from Davis, one of the many indirect acts of influence through which Davis played a significant part in Labour Party finances. ${ }^{23}$ Soon after his election Lee wrote an anonymous attack on "Beer Barons in Press and Politics" for the Worker, an act that Lee's biographer, Erik Olssen, regarded as a warning to the Trade that he was an independent voice. ${ }^{24}$ Whether or not Davis knew of this declaration, it was not surprising that he wanted to meet Lee, the young politician who had become an MP within three years of returning from service in the First World War. Lee was a non-drinker, but not a prohibitionist. He supported the state control option favoured 
by Savage and was thus a potential parliamentary asset for the Trade. His appeal for the Labour Party itself was obvious. Not only was he a decorated veteran with a conspicuously missing arm, an asset for a political party in which leading members had spent time in jail for opposing conscription, but he was already giving evidence of his energy and power as an orator. Davis was also a constituent, as he lived within Lee's electorate, Auckland East. Moreover, there seemed to be an affinity between the two men. Though Davis had grown up in a wealthy family, he was, like Lee, a rebel as a young man, often absent from his school, Auckland Grammar, and described by a master in his last report as "utterly incorrigible." ${ }^{25}$ Lee liked him and acknowledged his persuasiveness, despite his ruthless pursuit of the interests of the Trade. "Sir Booze" was, in fact, rather like Lee himself - energetic, reckless about convention, curious, and public-spirited.

Davis seemed to have a soft spot for the flamboyant young politician, for he gave Lee a job as manager of the Palace Hotel in Rotorua after Lee lost his seat in the 1928 election. This seems to have been the unintended result of a boundary change which destroyed Lee's majority in Auckland East and which had been brought about by a last-minute petition by brewery workers. The petition objected to a proposal which would have placed the city's trotting course in a dry area, Parnell. Part of Parnell was put, instead, into Lee's electorate and, as Lee described it, the success of the petition meant that "the racegoer could still have his beer," but it was clear that he himself was now likely to lose a seat that he had previously held with a majority of 750 votes. ${ }^{26}$ Lee says that when he found out the threat to his position, Davis phoned him to say he was full of regrets and promised that he would not let him down. ${ }^{27}$ Lee lost his seat, but Davis kept his word and gave Lee the job in Rotorua.

This incident is typical of the many stories from For Mine is the Kingdom that have the ring of truth, but are hard to verify. One aspect of Lee's work in Rotorua is, however, supported by other evidence. He claimed he was continually asked to provide cheap or free accommodation to anyone who could advance the firm's interests. ${ }^{28}$ Though he said in a letter to Conrad Bollinger in 1971 that he had a "sheaf" of letters requesting such benefits, only one appears to have survived. ${ }^{29}$ It may be that Lee kept it because it was signed by Davis himself and typed on Hancock and Co. stationery. The letter requests that "Mr Bellows, Inspector of Labour," together with his wife, be charged 10 shillings a day for their stay at the Palace Hotel ${ }^{30}$ Lee scribbled a comment on the letter:

This was Sir Ernest. He was a great giver at the expense of the state. Key people of importance became his guests, customs inspectors, politicians Labour, or Tory MPs. Most were poor and he had cash. Yet I was not for sale.

The threat of prohibition eased after the failure in 1925 of a Licensing Bill introduced by the Prime Minister, Gordon Coates. The Trade had supported Coates' Bill, a misjudgement in Lee's view. Lee told Davis this at the time, but the brewer was too busy lobbying MPs to take notice. According to Lee, Davis told him that he had gone as far as to have "fixed" a few members, with the implication that this was by paying them off in some way. ${ }^{31}$ Lee also claims that Davis had a problem in securing the vote of Parry, an anti- prohibitionist, as Parry was so ill with venereal disease that he was unable to take his place in Parliament and was sick in bed in the nearby Midland Hotel. Lee believed that Parry been on Davis' payroll for years, but acknowledged that, despite this assistance, Parry remained a committed socialist who was cynical about any support Davis gave to the Labour Party. ${ }^{32}$ Like Lee himself, Parry thought it would be a bad day for Labour once there was no fear of prohibition. The Trade would then be free to unite with other big businesses. ${ }^{33}$ Until then, however, there were a number of synergies between the interests of the Trade and the Labour Party. Lee noted, for example, that 
during the early period when the Trade supported Labour at the polls in the form of funds for canvassing, this was in the "wet" areas. These were the same areas where both Labour and the Trade did best. ${ }^{34}$

During election campaigns the Trade never donated to the Labour Party itself but made donations directly to candidates or through intermediaries such as Savage, Parry, and Mark Fagan, who was a long-standing Labour Party official and Speaker of the Legislative Council from 1939 to 1947. Lee said that without this money he could never have afforded to hire halls and advertise meetings. Lee also recalled the occasions when he was given a Christmas parcel of a few dozen beer, bottles of wine and a bottle of whisky. ${ }^{35}$ In all his early campaigns there was no support from head office, nor were the unions big financial supporters of the Labour Party until it finally took office in $1935 .{ }^{36}$ The chronic shortage of money for Labour in the years before it took office is detailed by Jim Franks and Peter McAloon in their history of the Labour Party. ${ }^{37}$ An indicator of the fragility of Labour's finances can also be seen in the opening address of the Party President, H. D. (Tim) Armstrong, at the 1935 Labour Party Conference. He observed that up till then the party had relied largely on the voluntary subscriptions of wage-earners, but this source of funds was currently limited by wage reductions and unemployment. ${ }^{38}$

How much of the money given to Labour candidates came directly from Davis and how much came from the campaign slush fund set up the Trade (the Trade Defence Fund) is unknown, but an indication of the size of the fund emerged years later at the hearings of the Royal Commission on Licensing in 1945-46. The Trade went as far as the Court of Appeal to block any examination by the Commission of how much it paid to the funds of political parties. The Commission was able, however, to obtain some estimates of how much money the Trade Defence Fund had available each year - the lowest estimate for 1945 was $£ 40,000$ ( $\$ 3,258,000$ in 2016 dollars). This money was spent by the officials in control of it, without any oversight by the firms that had contributed. ${ }^{39}$

In return for support by Davis, Lee kept him informed about events in Parliament. He had regular discussion with Davis in 1925 about how various parliamentarians were likely to vote on Coates' Licensing Bill, but says he was only taking the numbers: "I didn't intend to become a tool of the Trade, but I had no desire to lose my seat and my right to advance political and economic welfare issues." $40 \mathrm{He}$ said that he could have benefitted financially from his relationship with Davis. At the time of the formation of New Zealand Breweries in 1923, Davis offered Lee the opportunity to take up shares in the public part of the float and said he would lend him the money to do so, as well as help to hide Lee's holding in a brewery company by the use of a trust. Lee refused. ${ }^{41}$

\section{Payoffs and Villians}

Lee may not have enriched himself through the help of Davis, but he was sure that others had. He singles out the trade unionists Fintan Patrick Walsh and Frederick Young as principal allies of Davis and as actors in his own expulsion from the Labour Party. He is scathing about these enemies. Walsh, the president of the Seaman's Union, is variously described as a "gangster," a "strong-arm man," and "not above theft, slugging or manslaughter ... certainly a public liar.",42 Young, the secretary of the Hotel Workers' Union, is identified as one of the sadistic NCOs described in Lee's First World War novel, Civilian into Soldier, published in 1937, as well as being a black marketer during his war service, a "gangster," the creator of a secret society within his union in order to spy on its members, a violent anti-semite, and an underground member of the Communist Party. ${ }^{43}$ 
Most of the allegations Lee makes about these two are not relevant here. With one exception, Lee was never able to substantiate his belief that both Walsh and Young received payoffs from Davis, though he noted that both had unexplained wealth - evidenced by the large estate of $£ 72,000$ left by Walsh when he died in 1963 and Young's ownership of an expensive racehorse. ${ }^{44}$ Even the exception which ties Walsh to payments from Davis came by accident. When Conrad Bollinger was researching the history of the Seamen's Union in 1971, he found some of Walsh's private papers among those of the union. They included the evidence that Davis had paid at least $£ 1,000$ towards the costs incurred by Walsh in a libel action brought against him by Tony Neary, of the Carpenters' Union. ${ }^{45}$ In a handwritten note added to his record of his exchanges with Bollinger, Lee observed that, "There is always a behind the scenes scoundrel but it takes time for the truth to be told." 46

Some of the actions of Walsh and Young that Lee describes are borne out by other sources, such as the threat by Walsh to throw Lee out a window when he objected to dubious fundraising activities for the Russian Famine Relief Committee. ${ }^{47}$ The most serious of Lee's allegations, however, was that Young had conspired to sabotage the candidacy of H. G. R. Mason for the Auckland mayoral election in 1935, so that Davis could win. Young had enough influence over the delegates to the Labour Representation Committee in Auckland to ensure that a weaker Labour candidate, Joseph Sayegh, would be chosen instead of Mason. This was despite the fact that Mason was a leading member of the Labour Party. He had been the president of the party in 1931 and later held several cabinet posts. Young's machinations were so blatant that he was called to account at the 9th session of the Annual Conference of the Labour Party in April 1935. He was in trouble for a number of other reasons as well, which included his disloyal and derogatory comments about Labour Party MPs at the Conference of the Alliance of Labour. ${ }^{48}$ Party members' fury about the behaviour of Young dominated much of the conference's opening session and was covered with relish by NZ Truth, under the heading "ROWS AND ROARS AT CONFERENCE Labour Delegates Bitter about Party's Inner Workings." 49

A Committee of Inquiry was set up to report on the activities of the Auckland Labour Representation Committee (LRC). It found that Young had submitted a mock ballot paper to the LRC that marked the mayoral candidates in order of selection and that this was "... detrimental to the interest of the Party and is not likely to ensure the selection of the best candidate. ${ }^{\circ 50}$

Lee's own account of aspects of these events is substantially vindicated by the official record in the minutes, in which there is also mention of statements "... covering rumours relative to the payment of money to persons in connection with Mr. Davis' candidature." ${ }^{51}$ An amendment to a motion censuring Young for his disloyalty is set out in full in For Mine is the Kingdom:

That this conference is definitely of the opinion that the Auckland Labour Representation Committee has acted detrimentally to the Party in selecting its present candidate for the Mayoralty, thus playing into the hands of Labour's enemies by laying the Party open to the charge that it is the accomplice of the brewing interests. ${ }^{52}$

The amendment had been moved by Peter Fraser and seconded by Bob Semple. Lee incorrectly says that it was amended to remove the reference to brewing interests, for the entire amendment was actually withdrawn by consent of the conference. ${ }^{53}$ The fact that it was put forward at all, together with its reference to brewing interests, indicates much about the character of the discussion about Young and the suspicions about the role of Davis. 
Lee believed that it was the nearness of the forthcoming general election that saved Young, who was censured and only survived a resolution to expel him from the Labour Party by 44 votes to $41 .^{54}$ It was not long afterwards that Young was able to pay 400 guineas to buy a racehorse. ${ }^{55}$ Davis' generosity in this instance is implied in Lee's account, unlike a more straightforward gift from Davis' brother Eliot, who mentions in his autobiography that he gave the stallion, King March, to Bob Semple. ${ }^{56}$

Lee's view that Young acted at the behest of Davis and may have received benefits as a result seems very likely. He says that Savage himself concurred with the move to support Davis. In one of his reconstructed conversations (if that is a fair way to describe his method), he reports Savage's view as follows: "Young is a crook,' said Savage, "but why not let Sir Ernest Booze have the mayoralty?"57

Some discreditable aspects of Lee's own role in the mayoral election are glossed over in For Mine is the Kingdom. In Lees' view, Sayegh, the candidate promoted by Young for the Auckland mayoralty, was little better than a "ventriloquist's dummy," who obediently uttered election material prepared by Lee. ${ }^{58}$ Sayegh, a restauranteur of Assyrian descent, was described by Lee to national executive members as a "dumb wop" who spoke poor English. Despite Lee's scornful characterisation of Sayegh, the election itself turned out to be very close. Davis won by only 363 votes and Sayegh topped the vote for the council. ${ }^{59}$

Lee wondered how large a donation in return Savage might have received towards Labour's 1935 campaign. ${ }^{60}$ This statement appears to be unjustly coloured by Lee's enmity towards Savage, as the latter had urged the National Executive to endorse Mason as Labour's mayoral candidate. ${ }^{61}$ If Savage had supported Davis, it may have been only after his efforts on behalf of Mason had failed. Despite slips such as this, the general accuracy of Lee's version of the background to Davis' election provides a degree of credibility to associated stories about Davis that are more difficult to verify. For Mine is the Kingdom repeatedly illustrates the brewer's capacity to manipulate figures in the Labour Party. For Lee, the most galling aspect of the whole mayoralty affair was that the "gangster" Young was appointed to the Legislative Council in 1941, and was thereafter the Honourable Frederick Young. ${ }^{62}$

The degree to which Young could be seen as a hireling of Davis was illustrated by another incident, one which is not mentioned by Lee. Henry Kelliher, who headed the rival brewery group, Dominion Breweries, was being obstructed by the demand by Young's Hotel Workers' Union that there should be twenty-five waitresses in the dining-room of the St George Hotel, however many diners were there. Savage, who was in his office with Kelliher at the time, immediately phoned Young and told him that threatening industrial action over such pretexts was a discredit to the union and he should leave Kelliher and Davis to fight out their own battles. $^{63}$

For Mine is the Kingdom conveniently omits the story of how Young and Davis had helped Lee in an electoral campaign of his own, his challenge for nomination to the Grey Lynn seat prior to the 1931 election. In doing so, he had to defeat Fred Bartram, who had been the MP from 1919-1928. Bartram's backers claimed that Lee had said that he was a drunk and a bankrupt. Though some of the unsavoury rumours about the Lee campaign could not be proven, the displacement of a man who had been the long-standing MP for the seat upset delegates to the 1931 Conference. Among their objections was the fact that Young had advised members of the Hotel Workers' Union to back Lee. ${ }^{64}$ Davis, for his part, had paid for taxis to take Lee's 
supporters to the polling booth. ${ }^{65}$ Lee won, but the result was overturned at the 1931 Conference and Lee subsequently took the nomination again after another election organised by the National Executive. While the affair is further evidence of the influence of Davis and Young, it remains an example of the need for caution in accepting Lee's versions of political events and the true degree of support he himself might have received from Davis or, for that matter, even his enemy, Young.

\section{Psychobiography as history}

It is easy enough to dismiss Lee's memoir as a reliable historical document. So many of the events described in it depend entirely on his own recollections (and omissions). It is also limited by the uncertain mix of descriptions of actual happenings and the many reconstructed or imagined conversations. In the only extended analysis of Lee's method in For Mine is the Kingdom, V. Dupont suggests that Lee's method can be characterised as a new composite genre, a "character story." 66 The work might better be described as a psychobiography, a genre which attracted Lee and had a fateful expression in his article directed at Savage in 1939, "Psychopathology in Politics," which was one of the catalysts for his expulsion from the Labour Party the following year. ${ }^{67}$

Lee's book is not only an exposé of the brewer's actions in defence of the Trade. It is also an attempt to give a sense of the complexity of Davis as a person and the charm and unpredictability of the man. In the foreword to an earlier series of notes about his contemporaries, Lee said that he had always been interested in human behaviour, even the trivia that "crowds the life of the most purposeful... [M] any a great one has paused on the way to an historic beginning to look at an ankle or tell a story." ${ }^{68}$ It is true that he was fascinated by the secret lives of people he knew and what motivated them. His unpublished observations in the archive he left to the Auckland City Library, which include further material about Davis, are full of such trivia, as well as scandalous claims about many individuals that are very much in the same vein as his comments about Parry. ${ }^{69}$ Yet it would be a mistake to believe that For Mine is the Kingdom is just another instance of Lee's love of gossip.

Lee knew Davis well. Their acquaintance stretched over nearly 50 years, starting in 1914 when Lee was working as a porter in Auckland's Wynyard Hotel. It was one of the 200 hotels owned by Hancock and Co. Lee recounts how one night a young waitress at the Wynyard turned down an invitation from Davis and spent the evening at the Auckland Domain with him instead. ${ }^{70}$ Davis was finally successful after he offered to double the woman's wages and arranged for her to have an office job in Fiji. For Lee, this incident was an early part of his education about capitalism and the power of money:

I read about capitalists in tracts, capitalists in the abstract, but here was the living seeable presence. I was all eyes and ears as Booze used his job power to persuade girls to his bed. ${ }^{71}$

Davis was a persistent womaniser who shared many memories of his affairs with Lee and was unabashed by how he had exercised his "job power." He was loyal to his mistresses, however, and once he was finished with them he would sometimes find better jobs for them in his hotels, even as the wife of one of his managers. One son, according to Lee, worked at Hancock's bottle store, while other illegitimate offspring of Davis are mentioned in Lee's unpublished notes. ${ }^{72}$ Lee both admired Davis and was appalled by him, even when he had a late-life infatuation with the actress Vivien Leigh. In defence of Davis, Lee regrets in For Mine is the Kingdom that these events meant that the brewer's career had ended in ridicule, but he says that even in Davis' dotage he had demonstrated that he could still be a "gallant escort."73 
The importance of the description of Davis' affairs in For Mine is the Kingdom is that the accumulation of Davis' reminiscences, occasionally rueful, but more often in the form of boastful confidences to the younger man, become emblematic of a sinister power that was exercised both in politics and in the privacy of the bedroom. Far from taking away from the force of the book, Lee's rather prurient detailing of Davis' sexual conquests tells much about the nature of the man behind the public façade and his enormous capacity to manipulate people and events. ${ }^{74}$

It seems likely that Lee had hoped that his book would be as successful as Frank Hardy's tellall narrative, the novel Power without Glory. Lee's borrowing from the Lord's Prayer in his title For Mine is the Kingdom echoes the Australian's use of the same source in his book, published in 1950. The "John West" of Hardy's novel was based upon a Davis-like figure, the Melbourne businessman John Wren, whose fortune originated from his days running illegal betting shops in Collingwood. Like Davis in New Zealand, Wren also had an influential role behind the scenes in the affairs of the Labour Party in Victoria, while he was also said to have corrupted policemen and fixed sporting events.

Jack Lindsay described Power without Glory as a project which aimed to give "a general picture of the real sources of power in Australian politics." to produce a book which might enter "the mysterious world of the shadow world and recreate the man of whom people spoke in whispers with fear, hatred, admiration, and awe." 76 Davis, the political manipulator and power behind the Trade's secretive slush fund, as well as the capitalist who used his wealth and authority to seduce his employees, was very much a figure of such a "shadow world" and the representative of one of the "real sources of power" in politics.

It would have been almost impossible for Lee, in his later business as a bookseller, not to have known about Hardy, as in 1951 the latter was the defendant in a sensational trial for criminal libel. This was based on the presentation in his novel of "Ellen West" (Wren's wife Nellie) as a woman who had an adulterous affair with a handsome bricklayer. For Lee, the parallel between "Booze"-Davis and "West"-Wren must have been irresistible, especially because he had the advantage that he knew Davis personally, whereas Hardy had to collect his material about Wren at second hand. In terms of quality, however, Lee's work falls below Hardy's. Even though the Australian writer shared some of Lee's tendency towards exaggeration and melodrama, Power without Glory is a more convincing work of fiction, as is the case in other work in which Hardy wrote about subjects familiar to Lee, such as petty crime, itinerant workers, and characters in rural towns. ${ }^{77}$

Power without Glory was viewed by some readers as a true roman à clef and glossaries were circulated at the time that identified the supposed real names of the characters, but its many distortions and errors have meant that Hardy's novel can only be taken as a generalised representation of a type of businessman, rather than an accurate biography of Wren. ${ }^{78}$ Lee's book also makes tantalising claims for authenticity but is itself a generalised representation of a ruthless businessman who is prepared to use thuggish associates to get his own way. It constantly provokes doubt about what is an accurate account of events and what is owed to Lee's tendencies to exaggerate and confabulate.

A dismissive response to the book on such grounds came from Auckland historian R. C. J. 
Stone, who expressed his frustration that the only unguarded accounts of the activities of Davis and his associates came from two sources. One was Lee, whom Stone described as a "notorious political fantasist,"79 while the other was J. W. S. McArthur, whose Investment Executive Trust was exposed in the mid-1930s as the principal instrument of a number of outright swindles. Without saying why, Stone concluded that Lee's portrait of Davis as someone who corrupted politicians and unionists in order to protect the beer and spirits trade "obviously" fell "well short of reality." $" 80$

Stone went too far - there are important revelations in Lee's memoir about the Trade and its financial links with Labour. However, by presenting his account of Davis in a semi-novelistic form, Lee left himself open to such criticisms. His own autobiographical novels, starting with Children of the Poor in 1934, had the advantage that he was writing largely about himself, rather than trying to bring to life a well-known public figure such as Davis by devices such as remembered conversations. These do work at times, especially in the scenes between the narrator and Davis. Dupont is one reader who appreciates what he calls the "Gents' Saloon Bar" exchanges in these meetings. ${ }^{81} \mathrm{He}$ also points out the skilful contrasts between Davis' circumlocutory accounts of his affairs and Lee's blunter assessments of them. However, when one comes to the machinations of the Trade, Lee's diatribes about his political enemies are so extreme that this immediately makes one suspicious about the accuracy of many of his claims.

As an interesting but flawed work, For Mine is the Kingdom demonstrates both the strengths and weaknesses of psychobiography. The way Davis is represented, especially in his private dealings with women employees, helps to explain the almost psychopathic sense of entitlement that also allowed him to bribe and coerce his way through the complex world of liquor politics. As Lee saw it, this was "real politics ... the strange alliance that formed as the beer and liquor trade struggled to live, the beer barons who clawed their way to profit through the mire of booze and broken homes." 82

Davis' political acceptability grew through his later years, the period of his time as mayor of Auckland and generous philanthropist. Fraser, who had proposed the resolution at the 1935 Conference to censure Young about his actions during the 1935 Auckland mayoral campaign, became close enough to Davis to stay at Highfield, the brewer's Rotorua estate, while convalescing in 1950 after bouts in hospital. Bollinger found a note Davis wrote to Walsh about these visits. It included a photo, which Bollinger described to Lee:

One thing will delight you ... [is] a photo of Peter Fraser in homburg \& dark suit sitting in ED's shooting brake with a chauffeur driving \& the booze king in a huntin' shootin' fishin' hat sitting on the dickie breathing down Peter's neck. That's symbolic if you like! ${ }^{83}$

Symbolic indeed, if one thinks of the degree to which Davis had influenced or controlled Labour Party MPs and union leaders. When Davis died, Lee described it as a loss for the thousands who had seen Davis as a friend. He had almost become an Auckland institution. ${ }^{84}$ Lee's memoir contains the same paradoxes. Although he had set out to describe how Davis had been an unacknowledged and sometimes destructive player in the early history of the Labour Party, the warmth of much of his friendship with the brewer is obvious. While For Mine is the Kingdom is an important account of the role of the New Zealand liquor industry in early 20th century politics, it is also an absorbing portrait of the "shadowland operator" himself and his ruthlessness in defence of the Trade. 


\section{References}

All references to Lee's papers held in the Sir George Grey Special Collections in the Auckland City Library are under the heading NZMS828. Kate De Courcey and Iain Sharp were extremely helpful to me in navigating the Lee archive, while I also appreciated the opportunity to discuss the Lee-Davis connection in a seminar at the Stout Centre for New Zealand Studies at Victoria University on October 5, 2016. Thanks also to Dr Dianna Lacy, Labour Party Assistant Secretary, who kindly made available the minutes of the Labour Party Annual Conference of 1935 and to Dr Jim McAloon and Ray Grover, who also helped with suggestions about Lee and Davis. Apart from For Mine is the Kingdom, the principal source for Lee's links with Davis remains Erik Olssen's biography, John A. Lee, published in 1977 by Otago University Press.

\footnotetext{
Audrey Gordon, “On a Lee Shore,” NZ Women's Weekly (14 July 1975), 12-13.

John A. Lee, For Mine is the Kingdom (Martinborough: Alister Taylor, 1975), 7.

Letter to Conrad Bollinger, 16 March 1971, NZMS828 1/F3.

4 James Black, Unauthorised Biography of Sir Joseph Ward, Premier of New Zealand (Auckland: J
}

Black, 1910). Ward was the Colonial Treasurer when the collapse of his company led to his

bankruptcy and temporary exit from Parliament.

5 Nicky Hager, Dirty Politics, How Attack Politics is Poisoning New Zealand (Nelson: Craig Potton, 2014).

6 Robert A. Caro, The Power Broker, Robert Moses and the Fall of New York (New York: Vintage, 1975).

7 Graham Bush, "Davis, Ernest Hyam," from the Dictionary of New Zealand Biography, Te Arathe Encyclopedia of New Zealand', updated 7-June-2013,

www.TeAra.govt.nz/en/biographies/4d7/davis-ernest-hyam.

8 Bernard Foster, "Davis, Sir 'Ernest' Hyam Kt.," in An Encyclopaedia of New Zealand, ed. A.H.

McLintock (Wellington: Government Printer, 1966), 454.

9 Lee, Kingdom, 6.

10 Ibid., 141-44.

11 Lee had been thinking about such a book for many years and by 1967 was closer to completing it, according to a letter he wrote to Mary Scott on 8 March of that year: "The Davis book will see the light if I do it myself. Maybe about 1969 [...] Davis was a crook, but quite interesting. My publisher Collins is too far on the right to handle a person who gave a Queen a horse. Money casts haloes." NZMS828 6/F6.

12 Lee, Kingdom, 173.

13 Davis had a number of other business interests. Apart from his role as Chairman of Directors of brewers Hancock and Co. Ltd., and Chairman of NZ Breweries, in which he held a controlling interest, Davis was Chairman of the Devonport Stream Ferry Co, the North Shore Transport Co., The Northern Steamship Co, The Auckland Meat Co., and Bycroft Ltd.

14 Barry Gustafson, Labour's Path to Political Independence: The Origins and Establishment of the New Zealand Labour Party 1900-1909 (Auckland: Auckland University Press, 1980), 166.

15 Hon. Eliot Davis, A Link with the Past (Auckland: Oswald-Sealey, 1948), 94.

16 Eliot Davis, Link, 100.

17 Ibid., 102.

18 Richard Newman, "New Zealand's Vote for Prohibition in 1911", New Zealand Journal of History 9 (1975): 52-66.

19 May Bailey (nee Fowlds). My grandmother. The "top line" was the line on the voting paper in alcohol polls that offered the option of continuance, rather than prohibition.

20 McCombs became a reluctant supporter of the April 1919 poll in which there was a straightforward contest between prohibition and continuance, even though this might mean the payment of compensation if the liquor industry lost. This was because a simple majority would be sufficient to carry the day for prohibition, rather than the two-thirds majority required by previous 
polls. J. McCombs, MP, "Labour and the Licensing Referendum.” Maoriland Worker 10, no. 680 (29 March 1919): 3. paperspast.natlib.govt.nz/newspapers/MW19190329.2.17. Accessed 12 December 2016.

21 Gustafson, Labour's Path, 166.

22 Barry Gustafson, From the Cradle to the Grave: A Biography of Michael Joseph Savage (Auckland: Reed Methuen, 1986), 103-04.

23 Lee, Kingdom, 63.

24 Erik Olssen, John A. Lee (Dunedin: University of Otago Press, 1977), 55.

25 Eliot Davis, Link, 254.

26 Lee, Kingdom, 96.

27 Ibid., 97. Davis' support for Lee extended to financial backing for his return to Parliament in 1931 (see note 65).

28 Ibid., 109.

29 Letter to Conrad Bollinger, 27 March 1971, NZMS828 1/F3.

30 Letter from Davis to Lee, 9 February 1930, NZMS828 6/F14. This sum (\$96.00 in 2016 currency) was not out of line with hotel rates at the time in Rotorua. It may be that Davis was merely making sure that this individual got special attention from his hotel manager.

31 Lee, Kingdom, 89.

32 Ibid., 91-93. Lee also claims that Davis paid for Parry's treatment at Rotorua. Parry is not mentioned by name here, but is identified in Lee's unpublished note about the same incident: "Parry wanted em for no cost." NZMS828 23/F11, No. 9. n.d.

33 Ibid., 79.

34 Ibid., 79.

35 Ibid., 64.

36 Ibid., 77-78.

37 Peter Franks and Jim McAloon, Labour, The New Zealand Labour Party 1916-2016 (Wellington: Victoria University Press, 2016), 85-86.

38 Minutes of the 19th Annual Conference of the Labour Party, held in Wellington 22-24 April $1935,3$.

39 Conrad Bollinger, Grog's Own Country, The Story of Liquor Licensing in New Zealand, revised ed. (Auckland, Minerva, 1967), 81-82.

40 Lee, Kingdom, 80.

41 Ibid., 71-72. Lee's financial probity was challenged in other respects when it was revealed in May 1933 that he was a shareholder in four loan companies that lent money to workers at high rates of interest. This incident is described by Gustafson in From the Cradle to the Grave, 151.

42 Ibid., 139.

43 Ibid., 137-40.

44 Ibid., 146. Lee also said that when Walsh was on the Stabilisation Board he made money from his inside knowledge that the pound was to be appreciated and that no doubt he passed this information on to Davis. Among a number of other allegations about Walsh was the claim that he had organised the card vote at the Labour Party Conference in 1940 in order to expel Lee from the party.

45 John A. Lee, “A Social Document," MSS \& Archives A-235. Special Collections, University of Auckland Libraries and Learning Services. n.d. The 1971 claims about the payment to Neary were confirmed in 2004 when the records of the Service and Food Workers' Union (incorporating the Hotel Workers' Association) were donated to the Auckland University Library. Young facilitated the payment, and Graeme Hunt, Walsh's biographer, traces how the history of payments through the Hotel Workers' Association demonstrated that Davis funded at least part of Walsh's bill. Graeme Hunt, Black Prince, the Biography of Fintan Patrick Walsh (Auckland: Penguin, 1984), 186-87.

46 Lee, "A Social Document," 1.

47 Lee, Kingdom, 144. This event was also reported by Sid Scott, in his Rebel in a Wrong Cause (Auckland: Collins, 1960), 41.

48 Minutes of 1935 Conference, 22-23.

$49 \quad$ NZ Truth (24 April 1935), 11.

50 Minutes of 1935 Conference, 22. 
$51 \quad$ Ibid, 23.

52 Lee, Kingdom, 144.

53 Minutes of 1935 Conference, 23.

54 Lee, Kingdom, 144. This argument is supported by Keith Sinclair, in Walter Nash (Auckland: Auckland University Press, 1976), 110.

55 Lee, Kingdom, 143. The amount is equivalent to $\$ 45,000$ in 2016.

56 Eliot Davis, Link, 158. Perhaps not so generous, as Davis mentions that the horse had broken down when he gave it away.

57 Lee, Kingdom, 141.

58 Ibid., 143.

59 Gustafson, From the Cradle to the Grave, 161.

60 Lee, Kingdom, 143.

61 Sinclair, Walter Nash, 110. Sinclair provides another reason why Young may have received a degree of protection from Labour's National Executive, as in 1933 the Hotel and Restaurant Workers' Federation, controlled by Young, had rescued Labour's Head Office by paying $£ 100$ in fees for its members at a time when other unions' payments were in arrears.

62 Neill Atkinson suggests this may have been as a reward for helping in Lee's expulsion from the Labour Party in 1940. Neill Atkinson, "Young, Frederick George," From the Dictionary of New Zealand Biography. Te Ara -the Encyclopedia of New Zealand, www.TeAra.govt.nz/en/biographies/4y1/young-frederick-george. Accessed 24 January 2017.

63 Gustafson, From the Cradle to the Grave, 182.

64 Olssen, Lee, 52-53.

65 Gustafson, From the Cradle to the Grave, 150-51.

66 V. Dupont, "For Mine is the Kingdom"; A Book, A Man, An Author," The Commonwealth; Essays and Studies; Commonwealth: Publications de la Société francaise d'études du Commonwealth (Mont Saint-Aignan: J Leclaire, 1976), 113-33.

67 The text of this article is reproduced in Lee's Simple on a Soapbox (London: Collins, 1964), 16571. There is also an explanation of his reasons for writing it and a discussion of its impact. It was first published in the left-wing journal Tomorrow in December 1939.

68 John A. Lee, Political Notebooks (Wellington: Alister Taylor, 1973), 5-6.

69 Lee said of Davis, for example, that a $£ 2000$ sum for propaganda was provided to Labour from the Trade's slush fund and administered in the 1940s for Prime Minister Fraser by Mark Fagan, the Speaker of the Legislative Assembly. Letter to Conrad Bollinger, 27 March 1971, NZMS828 1/F3.

70 Lee, Kingdom, 16-19.

71 Ibid., 11.

72 NZMS858 23/F11, No. 9. n.d.

73 Lee, Kingdom, 174.

74 Ever conscious of the sales of his books, Lee commented on a review by Erik Olssen of For Mine is the Kingdom in which Olssen had said that he found the chapters about Davis' sexual pursuits "dull and pointless." Lee's scribbled response beside a clipping of the review in a scrapbook was: "Alas, if I had written only about booze Id [sic] have been lucky to [illegible] 500 copies." NZMS826 26/ F20.

75 Jack Lindsay, intr. to Power without Glory (North Sydney: Vintage Classics, 2008), 1-13. Lindsay's introduction was first published in 1968.

76 Frank Hardy, The Hard Way (Adelaide: Rigby, 1961), 39. This book was Hardy's own account of the dangers he faced in getting his novel published and the details of his subsequent trial for libel. This took place at the time when Australia was gripped by an anti-communist fervour in which a referendum to ban the Communist Party was only just defeated. Hardy himself was a member of the Communist Party.

77 As in his collection of stories, Legends from Benson's Valley (Ringwood, Victoria: Penguin, 1984).

78 James Griffin, John Wren, a Life Reconsidered (Melbourne: Scribe Publications, 2004). Griffin details many of the ways in which "John West" differed from Wren. 
79 R. C. J. Stone, “'Sinister' Auckland Business Cliques," New Zealand Journal of History 21, no. 2 (1987): 29-45 (35). www.nzjh.auckland.ac.nz/docs/1987/NZJH_21_1_07.pdf, Accessed 12 November 2016.

80 Ibid., 36.

81 Dupont, 127.

82 Lee, Kingdom, 176.

83 Bollinger, Letter to Lee, 31 March 1971, NZMS858 1/F3.

84 Lee, Kingdom, 175. 